\title{
NOTES AND COMMENTS
}

\section{HIGH COUMARIN 7-HYDROXYLASE ACTIVITY DOES NOT PROTECT MICE AGAINST WARFARIN}

\author{
IAN E. LUSH and C. J. ARNOLD \\ Department of Biology, Royal Free Hospital School of Medicine, London W.C.1
}

Received 11.iv.75

\section{SUMMARY}

Sixteen strains of mice varied widely in their ability to 7-hydroxylate injected coumarin to form umbelliferone, which is excreted in the urine. The same strains also varied in their resistance to the lethal effects of dietary Warfarin. There was no correlation between hydroxylating ability and Warfarin resistance.

WoOD AND CoNNEY (1974) have shown that strain DBA/2J mice have a much higher activity of liver coumarin 7-hydroxylase than do mice of strains $\mathrm{AKR} / \mathrm{J}, \mathrm{G} 57 \mathrm{BL} / 6 \mathrm{~J}$ and $\mathrm{C} 3 \mathrm{H} / \mathrm{HeJ}$. The difference is determined by a single gene, Coh, located near the gene Gpi-1 on chromosome 7 (Wood, personal communication). These authors also report that DBA/2J mice are less sensitive than $\mathrm{AKR} / \mathrm{J}$ mice to the lethal effects of the anticoagulant rodenticide Warfarin (3-( $\alpha$-acetonybenzyl)-4-hydroxycoumarin), and they raise the possibility that the two findings may be related since Warfarin is a coumarin derivative and is thought to be inactivated by hydroxylation.

We have compared 16 strains of mice with respect to their ability to hydroxylate coumarin and their resistance to dietary Warfarin. Coumarin hydroxylating ability was determined by the technique described by Wood and Conney (1974) in which a dose of $2.0 \mu$ mole of coumarin is injected i.p. into each mouse and the subsequent excretion of 7-hydroxycoumarin (umbelliferone) in the urine is measured spectrofluorimetrically. Warfarin resistance was measured by feeding mice on "Rodine" (a Rentokil product containing 0.05 per cent of racemic Warfarin) and noting how long they survived, up to 1 month.

The results are shown in table 1. With regard to Warfarin resistance, the outstanding strain was PBI, none of which showed any ill effects even after 3 months on "Rodine". This strain was developed by selection by Dr Margaret Wallace (1974a) at Cambridge from local Warfarin-resistant wild mice. Among the normal laboratory strains C3H, A2G, SM, GBA and perhaps Simpson showed some degree of resistance. The other strains were all very susceptible to Warfarin. With regard to the ability to hydroxylate coumarin the most efficient strain was DBA. Three other strains, CBA, NZB and G57L had an intermediate hydroxylating ability. All the other strains had a very low hydroxylating ability. There was no overlap between the three classes of hydroxylating ability.

From the data in table 1 one must conclude that the possession of high coumarin hydroxylating ability affords no protection against Warfarin poisoning in mice. Three of the four high-activity strains, including DBA, 
are very susceptible to Warfarin, and only one, CBA, shows some degree of resistance. It is probable that the strong Warfarin resistance possessed by PBI mice and the weak resistance of some laboratory strains are caused by different biochemical mechanisms. Wallace (1974b) has shown that resistance in PBI mice is largely determined by a gene, War, located on

TABLE 1

A comparison of Warfarin survival and umbelliferone excretion in 16 strains of mice

\begin{tabular}{|c|c|c|c|c|c|c|}
\hline \multirow[b]{2}{*}{ Strain } & \multicolumn{3}{|c|}{ Warfarin survival (days) } & \multicolumn{3}{|c|}{ Umbelliferone excretion ( $\mu$ moles) } \\
\hline & mean & (range) & number & mean & (range) & number \\
\hline PBI & $>90$ & - & 5 & 38 & $(31-50)$ & 3 \\
\hline $\mathrm{C} 3 \mathrm{H} / \mathrm{He} / \mathrm{Lac}$ & 14 & $(7-30)$ & 10 & 43 & $(37-47)$ & 3 \\
\hline $\mathrm{CBA} / \mathrm{Cam}$ & 14 & $(7-30)$ & 11 & 123 & $(98-168)$ & 5 \\
\hline $\mathrm{SM} / \mathrm{J}$ & 14 & $(6-30)$ & 11 & 47 & $(43-49)$ & 3 \\
\hline $\mathrm{A} 2 \mathrm{G} / \mathrm{Lac}$ & 13 & $(8-30)$ & 16 & 27 & $(15-43)$ & 3 \\
\hline Simpson & 10 & $(5-15)$ & 12 & 18 & $(13-22)$ & 3 \\
\hline C57BL/Lac & 8 & $(4-14)$ & 10 & 30 & $(22-36)$ & 3 \\
\hline NMRl/Lac & 7 & $(5-9)$ & 12 & 50 & $(36-64)$ & 3 \\
\hline $\mathrm{DBA} / 2 / \mathrm{Lac}$ & 7 & $(3-12)$ & 12 & 238 & $(226-250)$ & 5 \\
\hline $\mathrm{NZB} / \mathrm{Lac}$ & 7 & $(5-13)$ & 6 & 150 & (126-167) & 3 \\
\hline C57L/Lac & 7 & $(3-11)$ & 18 & 127 & (94-158) & 3 \\
\hline Schneider & 6 & $(5-9)$ & 10 & 24 & $(14-34)$ & 3 \\
\hline TO & 6 & $(3-9)$ & 10 & 27 & $(18-32)$ & 3 \\
\hline ICFW/Lac & 5 & $(3-8)$ & 16 & 34 & $(27-44)$ & 3 \\
\hline $\mathrm{F} / \mathrm{St} / \mathrm{Lac}$ & 5 & $(3-10)$ & 10 & 47 & (34-63) & 3 \\
\hline CE/Lac & 4 & $(2-8)$ & 9 & 33 & $(13-57)$ & 3 \\
\hline
\end{tabular}

All the mice were non-pregnant adult females maintained on Oxoid breeder diet. $2 \mu$ mole of coumarin in $0.1 \mathrm{ml}$ of 25 per cent ethanol were injected i.p. into each mouse which was then isolated for 22 hours, with drinking water ad libitum but no food, and the urine collec ted. The urine was diluted with water to a final volume of $50 \mathrm{ml}$. In order to free any conjugated umbelliferone a $5 \mathrm{ml}$ sample was incubated for 2 hours at $37^{\circ} \mathrm{C}$ with $0.2 \mathrm{ml}$ of a Helix pomatia extract (Sigma Ltd) containing 5500 Fishman units of $\beta$-glucuronidase plus some sulphatase activity. Umbelliferone fluorescence was measured in a Baird-Atomic Fluoripoint Spectrofluorimeter.

chromosome 7 near the gene "frizzy " $f r$, which is 20 units from the albino locus $c$. Greaves and Ayres (1969) found that the gene $R w^{1}$ which confers Warfarin resistance in Rattus norvegicus is also about 21 units from the homologous locus $c$ in that species. It therefore seems probable that major genes for Warfarin resistance in these two species are homologous (Wallace, 1975). In the rat, Warfarin resistance may be due to a genetic variant of the enzyme vitamin $\mathrm{K}$ oxide reductase (Bell and Caldwell, 1973; Zimmermann and Matschiner, 1974). Unpublished work by one of us (I. E. L.) has found that Warfarin resistance in laboratory strains of mice is correlated with hexobarbitone sleeping time in the same strains and may therefore be due to a hydroxylase, although clearly not coumarin 7-hydroxylase.

Acknowledgments. - This work was supported by the Nuffield Foundation and the Medical Research Council. Our thanks are due to Miss Jill Ford, A.I.A.T., for her care of the mice and to Dr Margaret Wallace and Miss Felicity MacSwiney for the PBI mice. 


\section{REFERENGES}

BELL, R. G., AND CALDWELL, P. T. 1973. Mechanism of Warfarin resistance. Warfarin and the metabolism of vitamin $\mathrm{K}_{1}$. Biochemistry, 180, 1759-1762.

GREAVES, J. H., AND AYRES, P. 1969. Linkages between genes for coat colour and resistance to Warfarin in Rattus norvegicus. Nature, Lond., 224, 284-285.

WALlace, M. E. 1974a. Mouse Newes Letter, 50, 28.

WAllace, M. Е. 1974b. Mouse Newes Letter, 51, 13.

Wallace, M. E. 1975. Mouse Newes Letter, 53, 20.

WOOD, A. W., AND CONNEY, A. H. 1974. Genetic variation in coumarin hydroxylase activity in the mouse (Mus musculus). Science, 185, 612-613.

ZIMMERMANN, A., AND MATSCHINER, J. T. 1974. Biochemical basis of hereditary resistance to Warfarin in the rat. Biochem. Pharmacol., 23, 1033-1040. 